\title{
GUA-GUA HUNIAN PRASEJARAH DI PULAU ROTE, INDONESIA TIMUR
}

\author{
Jatmiko \\ (Pusat Penelitian dan Pengembangan Arkeologi Nasional)
}

\begin{abstract}
This article is written based on the results of several archaeological investigations carried out by the National Research and Development Centre of Archaeology in prehistoric caves, in the Rotendao Regency on the Island of Rote, the Province of East Nusa Tenggara between 2006-2009. The investigations were focused on Mbia Hudale, Bafak, and Bote caves which are assumed to have prolific archaeological remains. Excavations on these caves reveal traces of human occupation dated back to Late Pleistocene - Holocene epoch. This is evident in the abundance of cultural remains found in these sites, such as plain and decorated potteries, mollusk shells, jewelry (beads) made of shell, lithic stone flakes and blades, as well as faunal remains. Not a single human bone was found during the excavations. Furthermore, archaeological surveys conducted in this area have identified 18 potential caves and rockshelters, as well as a Palaeolithic opensite which are scattered within 8 districts.

The results of the researches suggest that prehistoric caves in the Island of Rote are potential and prospective in illuminating prehistoric human migration and cultural processes that took place in the eastem part of Indonesia during Late Pleistocene until Holocene epoch.
\end{abstract}

Key words: Gua Prasejarah - Pulau Rote - Akhir Plestosen - Holosen

\section{GAMBARAN UMUM DAN PROFIL PULAU ROTE}

Pulau Rote yang terkenal dengan alat musik 'Sasando' dan topi 'Tii Langga'nya ini oleh bangsa asing lebih sering disebut "Roti". Pulau Rote adalah pulau terbesar di antara gugusan pulau yang tersebar di bagian baratdaya Pulau Timor. Gugusan pulau ini terdiri atas 96 pulau, dan hanya enam pulau yang berpenghuni. Dalam administratif pemerintahan, Kepulauan Rote merupakan bagian dari Provinsi Nusa Tenggara Timur dan secara geografis merupakan bagian dari rangkaian kepulauan yang lebih besar dan lebih luas, yang dikenal sebagai Kepulauan Nusa Tenggara atau Sunda Kecil (Lesser Sunda).

Pulau Rote merupakan salah satu kabupaten dalam wilayah Provinsi Nusa Tenggara Timur yang terletak pada posisi $122^{\circ} 35^{\prime}-123^{\circ} 30^{\prime}$ Bujur Timur dan $10^{\circ} 25^{\prime}-11^{\circ} 00^{\prime}$ Lintang Selatan. Luas Pulau Rote adalah 1.214,30 
$\mathrm{km}^{2}$, yang sebagian besar wilayahnya didominasi oleh lahan berbatu dan bukit-bukit kecil yang tidak terlalu curam. Daerah yang relatif datar terdapat di pinggir pantai, yang dulunya merupakan lahan tanaman kelapa dan sebagian padang rumput. Muka tanah yang berbukit batu ditambah dengan terbatasnya curah hujan menyebabkan lahan di daerah ini sangat tandus dan berhawa panas. Pada bulan tertentu cuaca pada malam hari sangat dingin. Ini dipengaruhi oleh perubahan cuaca di wilayah Australia karena letak geografis Pulau Rote yang sangat dekat dengan Benua Australia.

Pulau Rote yang berjarak sekitar $16 \mathrm{~km}$ dari ujung baratdaya Pulau Timor ini dikelilingi oleh Laut Sawu di utara dan barat, Laut Timor di timur, dan Lautan Hindia di selatan. Pulau ini berbentuk memanjang dengan keletakan membujur, kurang lebih, pada arah timurlaut-tenggara. Luas pulau mencapai $1,210 \mathrm{~km}^{2}$ dengan panjang sekitar $80 \mathrm{~km}$ dan bagian terlebar sekitar $23 \mathrm{~km}$.

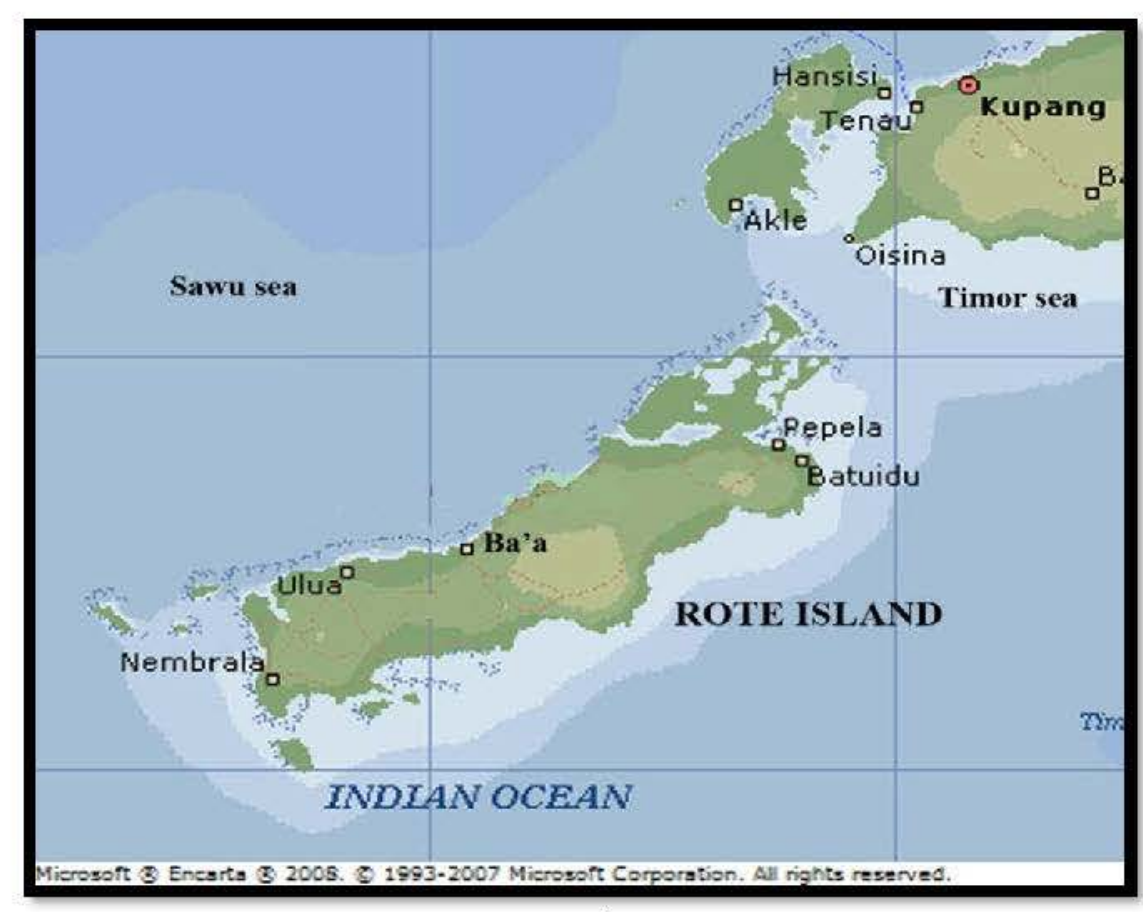

Peta 1. Pulau Rote

Seperti pulau-pulau lain di gugusan kepulauan Nusa Tenggara Timur pada umumnya, Pulau Rote termasuk beriklim kering yang dipengaruhi angin muson. Angin muson timur (April-Nopember) dicirikan oleh angin kencang membawa kekeringan pada umumnya. Sementara angin muson barat yang mulai sekitar akhir Nopember atau awal Desember hingga Maret dicirikan oleh angin kencang yang menimbulkan hujan deras dan sering diiringi dengan badai. Kondisi ini menjadikan lingkungan alamnya tergolong kering, terbuka dengan pepohonan yang jarang (open woodland). Di beberapa bagian, khususnya di bagian utara dan tengah, 
terdapat lingkungan yang lebih tertutup dan di beberapa tempat membentuk lingkungan hutan hujan tropis (tropical rain forest). Di wilayah pesisir bagian utara, hutan bakau tampak masih terkonservasi dan menutupi wilayah pasang surut.

Secara umum, geografi Pulau Rote tergolong datar. Bagian utara dan selatan berupa pantai dengan dataran rendah, sementara bagian tengah merupakan lembah dan perbukitan. Kondisi lingkungan yang lebih kering di bagian selatan menjadikan proses erosi lebih terlihat hingga membentuk tebing-tebing di sekitar perbukitan dan di tepi sungai-sungai kering. Umumnya pulau ini tersusun dari terumbu gamping yang memungkinkan terbentuknya gua-gua dan ceruk alam. Kondisi ini sangat cocok untuk lokasi hunian oleh manusia pada jaman prasejarah.

\section{LATAR BELAKANG DAN PERAN STRATEGIS ROTE PADA JAMAN PRASEJARAH}

Sebagai bagian dari gugusan kepulauan yang memanjang timurbarat dari Nusa Tenggara, Pulau Rote dan sekitarnya menjadi strategis dalam persebaran dan perkembangan hunian masa lampau. Terlebih lagi karena keletakannya yang menghadap ke Benua Australia, Pulau Rote dapat menjadi batu loncatan dalam persebaran manusia ke Australia. Berdasarkan keadaan inilah, para ahli sering melihat Pulau Rote sebagai bagian yang berperan dalam migrasi manusia anatomi modern ke arah timur dan Australia.

Menurut Birdsell (1977), walaupun tidak secara eksplisit menyebut Rote, kedekatan pulau ini dengan Pulau Timor, yang dipandangnya sebagai daerah rute migrasi, menjadikan pulau ini ikut berperan dalam proses migrasi manusia. Birdsell sendiri melihat ada dua kemungkinan jalur migrasi manusia anatomi modern Australia dan Papua. Jalur pertama melalui kepulauan Nusa Tenggara ke arah timur. Setelah sampai di Timor rute terpecah dua: yang satu menuju kepulauan Tanimbar hingga akhirnya tiba di Paparan Sahul, sedang yang lain dari Timor menuju wilayah Kimberley di Australia bagian utara. Jalur kedua melalui Kalimantan, Sulawesi, dan Maluku, hingga tiba di Paparan Sahul. Jika pendapat ini benar, maka pada jalur pertama itulah, khususnya cabang yang ke Australia Utara, Pulau Timor dapat lebih berperan, mengingat keletakannya yang paling dekat ke Benua Australia.

Data arkeologi sejauh ini memang belum memberikan jawaban yang memuaskan tentang kebenaran pendapat Birdsell, walaupun kondisi geografinya sangat mendukung. Para ahli umumnya sepakat bahwa kolonisasi Australia terjadi sekitar $50.000-60.000$ tahun lalu dan berlangsung lewat kepulauan Indonesia. Namun, pada kenyataan pertanggalan-pertanggalan tertua kolonisasi manusia modern awal di kepulauan Nusantara dan Asia Tenggara pada umumnya justru lebih muda dari pertanggalan Australia. Bukti-bukti hunian tertua misalnya sejauh ini 
ditemukan di Song Terus (c.45.000 BP) (Sémah et al. 2003; Simanjuntak 2001), Gua Niah (c.43.000 BP) (Barker et al. 2002), Gua Tabon, Filipina (c.40.000) (komunikasi pribadi dengan Dr. Bong Dizon), Ceruk Lang Rongrien di Thailand (Anderson 1990), Leang Burung 2 dan Leang Sakapao, Sulawesi (c. 30.000) (Glover 1981; Bulbeck et al. 2004), Gua Golo, Maluku (c. 34.000 BP) (Bellwood et al. 1998), dan Lie Siri, Timor Leste (c.31.000) (O'Connor et al. 2002). Pertanggalan yang lebih muda diperoleh dari kepulauan Aru (c. 28.000 BP) (Spriggs et al. 1998) dan Kepala Burung, Papua (c. 26.000 BP) (Pasveer, 2003).

Kesenjangan itu dapat saja dipengaruhi banyak faktor yang untuk mengungkapkannya membutuhkan analisis multi-disiplin. Namun, setidaknya data yang ada menunjukkan bahwa hunian purba di kawasan Asia Tenggara hingga Australia cenderung lebih muda ke arah timur. Data ini mengindikasikan sebaran hunian yang bergerak dari barat ke arah timur menjelang akhir Plestosen.

Bagaimana dengan Pulau Rote yang menjadi sasaran penelitian kali ini? Pada kenyataannya, pulau ini telah mendapat perhatian para ahli jauh sebelumnya dan masih berlanjut hingga sekarang. Adalah Alfred Bühler yang pertama-tama meneliti pulau ini dalam upaya memahami sejarah hunian. Di awal tahun 1930-an, Bühler yang juga meneliti Gua Niki-Niki dan gua-gua lainnya di daerah Atambua dan sekitarnya (Timor Barat) melebarkan penelitian ke Pulau Rote. Salah satu sasaran yang diteliti adalah gugusan gua dan ceruk di wilayah Desa Oemilan, Kecamatan Lombalain di dekat kantor polisi Kabupaten Rote Ndao sekarang. Hasil penelitiannya belum dapat memberikan posisi kronologi hunian gua di kala itu mengingat di kala itu metode pertanggalan radiometri $(\mathrm{C}-14$, dII) belum dikenal.

Hasil penelitian yang tergolong menonjol sesudah Bühler diperoleh oleh Mahirta, pengajar dari UGM yang melakukan eksplorasi dan ekskavasi di beberapa gua di wilayah ini untuk disertasi doktornya. Beberapa pertanggalan yang didapat dari penelitiannya menampakkan adanya jejakjejak hunian gua yang intensif di wilayah ini sejak Kala Holosen. Dari penelitiannya tersebut, berhasil ditemukan jejak hunian hingga sekitar 24.000 BP pada salah satu temuan gua di wilayah ini. Pertanggalan ini mencerminkan bahwa Pulau Rote merupakan salah satu pulau yang penting dalam sejarah persebaran manusia dan perkembangan budaya pada akhir Kala Plestosen yang berlanjut hingga Kala Holosen (Mahirta, 2004).

Bukti pertanggalan ini memperlihatkan kesejajaran dengan bukti yang baru-baru ini ditemukan di Lene Hara, Timor Leste (O'Connor et al, 2002). Dalam hal ini baik Pulau Rote maupun Pulau Timor yang terletak di timur laut-nya telah dieksploitasi manusia sejak sekitar 30.000 tahun yang lalu dan mungkin lebih tua lagi. Kondisi inilah yang melatarbelakangi penelitian ini dilaksanakan. Penelitian ini ingin memantapkan kronologi hunian dan perkembangan budaya di Pulau Rote, sekaligus ingin 
menelusuri sejarah persebaran atau migrasi manusia dalam konteks kawasan Indonesia Timur - Melanesia Barat - Australia.

Hasil-hasil penelitian yang dilakukan oleh para peneliti terdahulu kemudian ditindaklanjuti lagi oleh Puslit Arkenas pada tahun 2006 melalui survei permukaan untuk menjajagi potensi tinggalan arkeologi prasejarah di pulau ini. Dari hasil penelitian tersebut telah dapat diidentifikasi beberapa gua yang mempunyai prospek dan berpotensi untuk dilakukan penelitian lebih lanjut di antaranya adalah Gua Mbia Hudale dan Gua Tonggobatu-3. Dari hasil pengamatan terhadap gua-gua tersebut, telah didapatkan petunjuk di permukaan berupa alat-alat serpih batu yang sangat melimpah, sisa-sisa tulang fauna, cangkang kerang, dan gerabah (Jatmiko, 2006; Mahirta, 2004).

\section{BEBERAPA PERTANYAAN PENELITIAN}

Penghunian gua-gua alam oleh manusia merupakan suatu langkah dalam proses adaptasi manusia terhadap lingkungan. Simanjuntak (1994) menyatakan bahwa pemilihan gua-gua alam ini merupakan suatu tahap yang telah dicapai manusia sebelum hidup menetap. Karena itu, pada tahap ini manusia masih bertempat tinggal secara semi-sedentaire yang berarti suatu tingkat peralihan menuju kehidupan yang lebih sedentaire. Pendapat ini didasarkan pada adanya temuan himpunan artefak (assemblage) yang tersebar secara vertikal dan berkesinambungan. Gua merupakan tempat ideal untuk preservasi sisa-sisa kegiatan manusia masa lalu. Gua juga merupakan tempat berlindung bagi manusia dan binatang, karena gua-gua atau ceruk dianggap suatu tempat yang aman.

Tindakan untuk berlindung dan menghindar yang pada mulanya bersifat keputusan sesaat berdasarkan naluri, kemudian berkembang menjadi pengetahuan. Berdasarkan pengetahuan itu, mereka akhirnya memilih dan memanfaatkan gua-gua atau ceruk yang dianggap aman dan nyaman untuk bertempat tinggal. Tempat yang paling aman adalah tempat yang tidak mudah didatangi gangguan atau juga tempat yang mudah dipakai sebagai tempat pertahanan, misalnya untuk menghindar dari serangan binatang buas. Mereka mencari tempat-tempat yang tinggi, atau di balik batu-batu besar. Selain itu, tempat demikian juga harus terhindar dari panas, angin, dan hujan. Oleh karena itu, lokasi gua-gua yang mereka huni harus cukup luas untuk seluruh

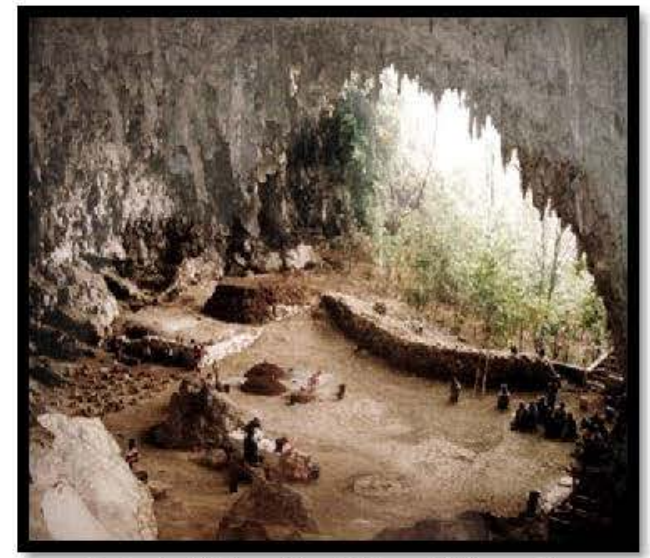

Foto 1. Situs Gua (Liang) Bua di anggota kelompok, dan mudah mencapainya serta mudah untuk mencari 
kebutuhan dasar, yaitu makanan dan sumber air minum (Eriawati, dkk., 1995).

Faktor pemilihan tempat tinggal erat kaitannya dengan pola kehidupan yang dijalankan pada masa itu yaitu berburu, menangkap ikan serta mengumpul bahan makanan yang berasal dari alam sekitarnya. Persoalan pemukiman manusia di gua-gua alam adalah sesuatu yang penting dalam perjalanan sejarah okupasi manusia pada waktu kurun prasejarah. Oleh sebab itu perlu dilakukan kajian untuk memahami lebih jauh seluk beluk penghunian manusia purba di gua-gua serta adaptasi manusia terhadap lingkungan sekitarnya. Pemilihan gua sebagai alternatif tempat tinggal manusia pada Akhir Plestosen hingga Awal Holosen (sering disebut: Masa Mesolitik) tentunya merupakan strategi yang dipilih saat itu. Karena itu, dalam kaitannya dengan gua tempat hunian, dapat diajukan pertanyaan penelitian: apakah terdapat pola-pola tertentu dalam memilih gua sebagai tempat hunian, ataukah pemilihan gua hanya sebagai tempat tinggal insidentil semata tanpa strategi tertentu.

Berdasarkan uraian di atas, maka gua merupakan salah satu tempat penyimpanan ideal untuk menelusuri sisa-sisa kehidupan masa lampau. Selain sebagai tempat perlindungan, gua juga dimanfaatkan sebagai tempat bermukim dan melakukan aktivitas sehari-hari oleh manusia pada masa lalu (prasejarah). Pemukiman manusia di gua-gua alam merupakan suatu persoalan yang sangat penting dalam upaya menelusuri perjalanan sejarah okupasi pada kurun waktu prasejarah. Dengan demikian perlu adanya beberapa kajian untuk memahami lebih jauh mengenai pemahaman terhadap penghunian manusia sebagai bentuk adaptasi dengan alam lingkungannya.

Kegiatan-kegiatan manusia yang dilakukan pada suatu lokasi situs gua akan memperhatikan kondisi lingkungan dan penguasaan teknologinya. Dengan demikian, kondisi lingkungan dianggap merupakan salah satu faktor penentu di dalam pemilihan lokasi situs. Menurut Butzer (1964), terdapat beberapa variabel yang berhubungan dengan kondisi lingkungan tersebut, antara lain:

- tersedianya kebutuhan akan air, adanya tempat berteduh, dan kondisi tanah yang tidak terlalu lembab

- tersedianya fasilitas-fasilitas yang diperlukan untuk bergerak lebih mudah (pantai, sungai, rawa, dan hutan)

- tersedianya sumber makanan baik berupa flora dan fauna serta faktorfaktor yang memberi kemudahan di dalam cara-cara perolehannya

Bertitik tolak dari uraian di atas, penelitian arkeologi prasejarah di Pulau Rote ini juga dimaksudkan untuk mengungkap beberapa permasalahan yang berkaitan dengan karakteristik gua-gua hunian prasejarah dan faktor-faktor yang berhubungan dengan lingkungan. Bagaimana ciri-ciri dan pola lingkungan yang ada pada situs-situs arkeologi prasejarah di wilayah ini ? Bagaimana ciri-ciri morfo-teknologi temuan budayanya dan sampai sejauh mana sebarannya ? Apakah tinggalan budaya prasejarah di wilayah ini mempunyai kaitan dengan bentuk-bentuk 
temuan serupa yang didapatkan di wilayah sekitar Indonesia Timur (NTT) lainnya ? Siapakah manusia pendukung budaya prasejarah tersebut? Topiktopik seperti ini merupakan permasalahan menarik yang akan dicoba dipecahkan dalam penelitian ini.

\section{DATA SEBARAN GUA-GUA DAN CERUK DI PULAU ROTE}

Kondisi geologis Pulau Rote - sebagaimana Pulau Timor pada umumnya - sebagian besar wilayahnya tersusun oleh batuan gamping terumbu yang memungkinkan terbentuknya gua-gua dan ceruk alam di pulau ini. Fitur-fitur alam inilah yang menjadi daya tarik penelitian selama ini, karena menjadi pusat orientasi kehidupan manusia di jaman prasejarah, khususnya sejak paruh kedua Plestosen Atas hingga awal Holosen. Seperti di daerah lain, berbagai jejak perilaku manusia dapat terekam pada lapisan hunian gua dan tinggalan yang dikandungnya. Himpunan artefak dan ekofak dapat menggambarkan kemajuan teknologi, cara-cara hidup (lifestyle, subsistensi), kemampuan dan strategi adaptasi lingkungan.

Penelitian-penelitian yang telah berlangsung selama ini telah berhasil mengidentifikasi sebagian gua dan ceruk serta mengekskavasi beberapa di antaranya, tetapi masih banyak gua dan ceruk lain yang belum terjangkau penelitian yang dilakukan selama ini. Kesulitan aksesibilitas, kekurangan informasi, dan keterbatasan waktu penelitian menjadi faktor penyebab masih banyaknya gua dan ceruk yang masih luput dari jamahan para peneliti. Namun, hasil-hasil penelitian terdahulu telah meyakinkan kita akan kekayaan gua dan ceruk di Pulau Rote.

Survei permukaan atau eksplorasi singkat yang dilakukan dalam penelitian, ternyata semakin memperlihatkan kekayaan gua dan ceruk di pulau ini. Kondisi alam pulau yang pada umumnya tersusun oleh gamping terumbu menjadikan hampir di seluruh wilayah pulau, terutama di sekitar perbukitan, terdapat gua dan ceruk. Untuk memperoleh gambaran tentang kekayaan dan potensi gua dan ceruk di wilayah Kabupaten Rote Ndao, selanjutnya akan diuraikan sebagai berikut. 


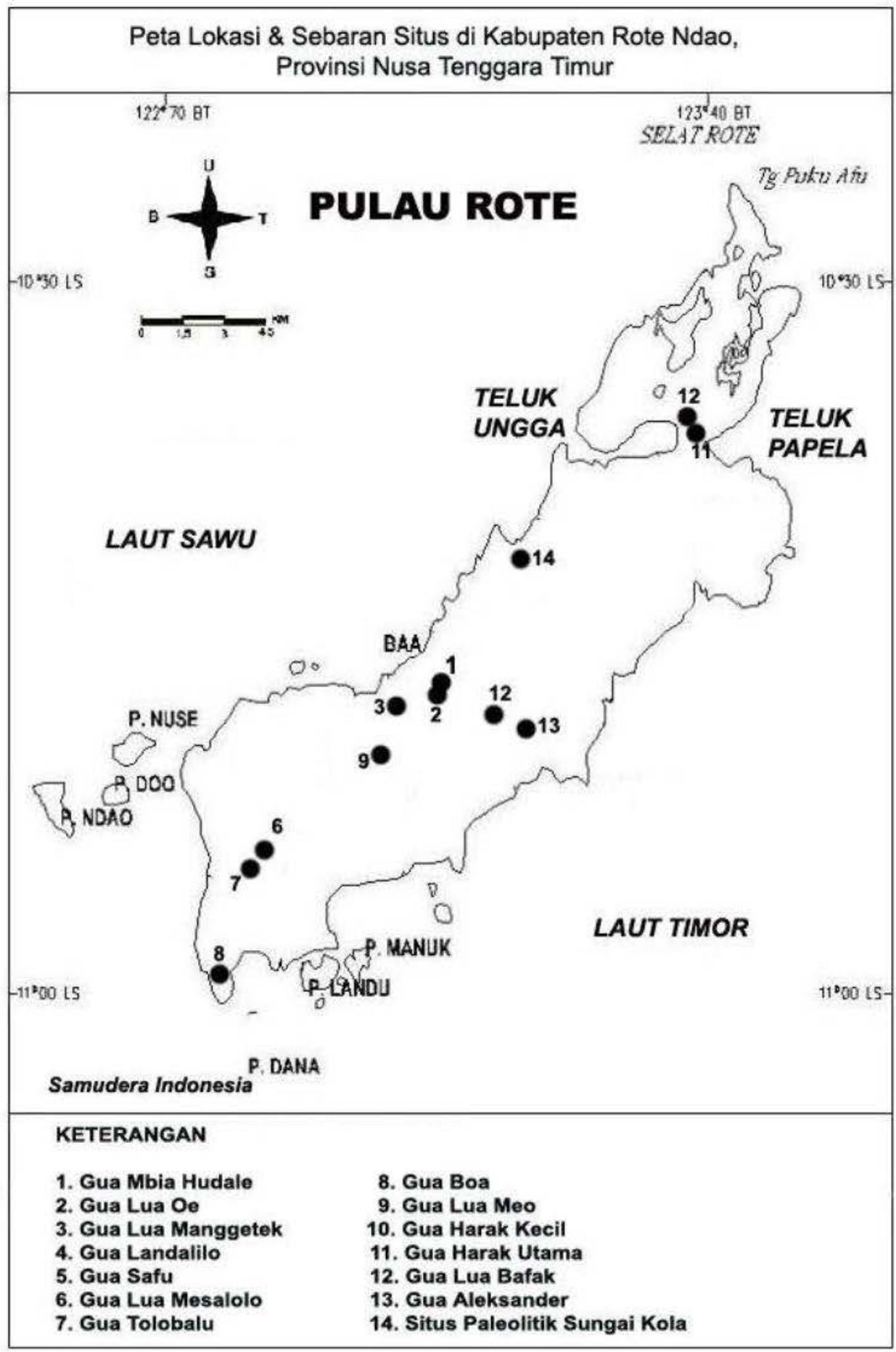

Peta 2. Sebaran Gua-gua dan Ceruk di Pulau Rote 


\section{* Gua Mbia Hudale}

Gua Mbia Hudale merupakan gua kaki bukit yang termasuk wilayah

Kelurahan Mokdale, Kecamatan Lobalain. Gua Mbia Hudale terletak pada $10^{\circ} 444^{\prime} 51,0^{\prime \prime}$ Lintang Selatan dan $123^{\circ}$ 03'15.0" Bujur Timur, dengan ketinggian 102 meter di atas permukaan airlaut.

Gua ini termasuk tipe ceruk dan berarah hadap Barat $\left(\mathrm{N} 270{ }^{\circ} \mathrm{E}\right)$, Kemiringan lantai teras $2^{\circ}-3^{\circ}$. Bentuk gua lebar menyamping, dengan sirkulasi dan intensitas sinar yang baik serta mempunyai ornamen berupa stalaktit dan stalagmit. Gua ini pernah diekskavasi

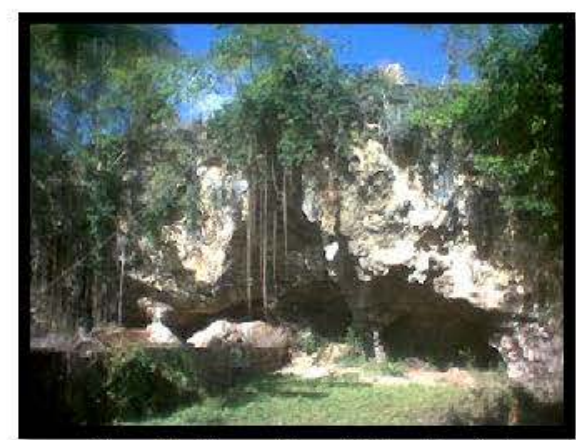

Foto 2. Situs Gua Mbia Hudale oleh Mahirta, pada tahun 2000. Dari hasil ekskavasi tersebut diperoleh berbagai temuan dari sisa-sisa tinggalan berciri Neolitik yang antara lain berupa cangkang kerang (banyak dimanfaatkan sebagai alat dan perhiasan), artefak batu (utamanya serpih), fragmen tembikar, sisa-sisa tulang manusia dan hewan. Hasil analisis pertanggalan $\mathrm{C}-14$ dari sampel arang tertua di gua ini berasal dari kurun waktu $11.000 \mathrm{BP}$ (Mahirta, 2004).

Pada tahun 2008, Puslitbang Arkenas melakukan penelitian ulang dengan membuka 3 kotak uji (masing-masing berukuran 1,5 x 1,5 meter) di gua ini. Dari hasil ekskavasi yang mencapai kedalaman hingga $85-95 \mathrm{~cm}$ tersebut didapatkan berbagai temuan antara lain berupa alat-alat litik (utamanya serpih) dan cangkang kerang yang sangat melimpah, serta fragmen tulang-tulang vertebrata. Satu manik-manik dan serut (berbentuk sendok) dari cangkang kerang juga ditemukan dalam ekskavasi di gua ini (Jatmiko dkk, 2008).

* Gua (Lua) Bafak

Lokasi Gua

administratif termasuk

(Lua) termasuk

Oematamboli, Kecamatan Lobalain. Gua Bafak terletak pada $10^{\circ} 45^{\prime} 37,3^{\prime \prime}$ Lintang Selatan dan $123^{\circ} 07^{\prime} 24,5^{\prime \prime}$ Bujur Timur, dengan ketinggian 265 meter di atas permukaan air laut. Gua ini terletak di tengah-tengah Pulau Rote. Gua ini menghadap Selatan $\left(\mathrm{N} 170{ }^{\circ} \mathrm{E}\right)$, dengan kemiringan $25^{\circ}$ dan ketinggian 5 meter dari dataran.

Lebar pintu gua 5 meter, tinggi pintu gua 2 meter, dan panjang kedalam 6 meter. Gua ini memiliki ornamen stalagtit, stalakmit, pilar, batu alir (flowstone), dengan sirkulasi udara dan intensitas sinar yang baik. Di gua ini dilakukan kegiatan ekskavasi dengan membuka satu unit kotak uji berukuran $2 \times 2$

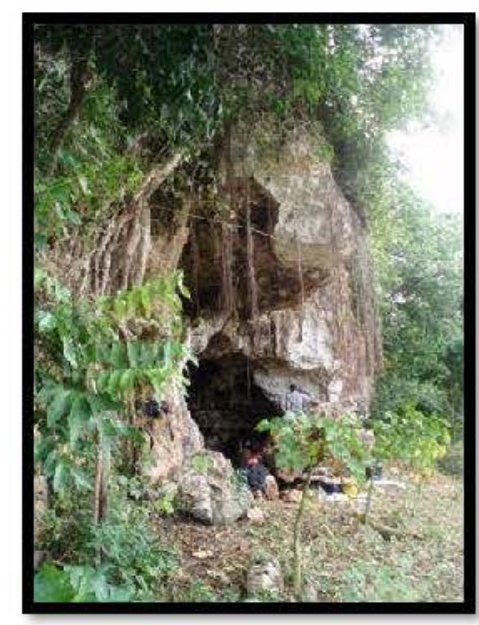

Foto 3. Pintu masuk Gua (Lua) Bafak 
meter dengan kedalaman maksimal antara $105-115 \mathrm{~cm}$. Temuan yang dihasilkan dalam ekskavasi antara berupa alat-alat litik (utamanya serpih) dan cangkang kerang yang sangat melimpah, fragmen tembikar (polos dan hias) dan fragmen tulang vertebrata. Selain itu, dalam ekskavasi ini juga ditemukan 2 manik-manik dari cangkang kerang (Jatmiko dkk, 2009).

\section{* Gua (Lua) Bote}

Lokasi Gua (Lua) Bote secara administratif masih termasuk wilayah Desa Oematamboli, Kecamatan Lobalain. Jarak Gua Bote ke Gua Bafak adalah 984 meter ke arah barat laut $\left(\mathrm{N} 312^{\circ} \mathrm{E}\right)$.

Gua Bote merupakan gua tebing yang secara astronomis terletak pada $10^{\circ} 45^{\prime} 58,6^{\prime \prime}$ Lintang Selatan dan $123^{\circ} 07^{\prime} 48,6^{\prime \prime}$ Bujur Timur, dengan ketinggian 300 meter di atas permukaan air laut, serta tercantum pada Peta Rupa Bumi Indonesia Lembar 2305-114 (Oele), berskala 1:25.000. Gua ini mempunyai arah hadap barat laut $\left(\mathrm{N} 300^{\circ} \mathrm{E}\right)$, dengan kemiringan $20^{\circ}$ dan

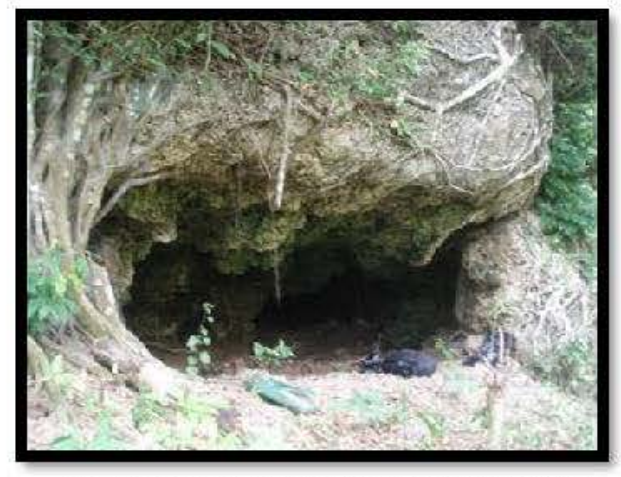

Foto 4. Pintu masuk Gua (Lua) Bote

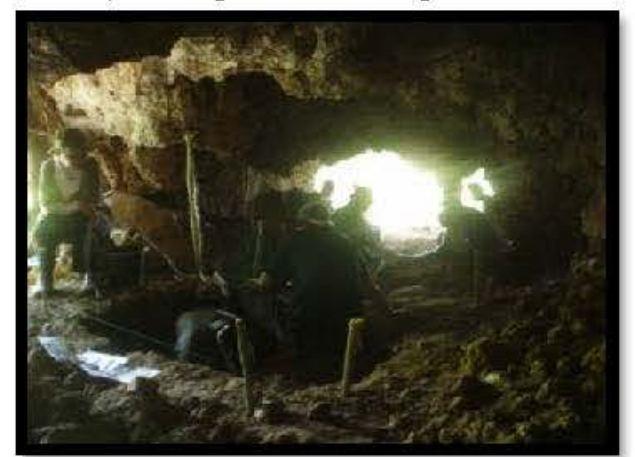

Foto 5. Aktivitas penggalian (ekskavasi) di Gua Bote

ketinggian 5 meter dari dataran. Lebar pintu utama 4,30 meter, tinggi pintu utama 1,65 meter, Lebar pintu kedua 1,80 meter, tinggi pintu kedua 1,55 meter. Ukuran ruang gua adalah lebar ruang 14 meter, panjang kedalam 6,5 meter, tinggi ruang dari lantai ke atap (tertinggi) 2,30 meter. Gua ini memiliki ornamen stalagtit, stalakmit, pilar, batu alir (flowstone), dengan sirkulasi udara dan intensitas sinar yang baik.

$\mathrm{Di}$ gua ini dilakukan kegiatan ekskavasi dengan membuka 2 kotak uji (masing-masing berukuran $1,5 \times 1,5$ meter) dan kedalaman maksimal antara $35-85 \mathrm{~cm}$. Temuan yang dihasilkan dalam ekskavasi ini antara lain berupa alat-alat litik (utamanya serpih, batu inti, batu pukul dan batu pelandas), serta cangkang kerang yang sangat melimpah, fragmen tembikar (polos dan hias) dan fragmen tulang/gigi

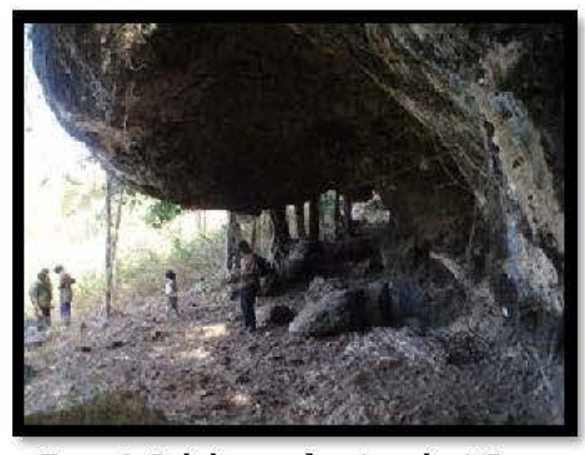

Foto 6. Salah satu bagian dari Gua Manggetek yang merupakan "rockshelter" 
vertebrata. Selain itu, ditemukan 3 manik-manik dari cangkang kerang (Jatmiko dkk, 2009).

\section{* Gua (Lua) Manggetek}

Gua (Lua) Manggetek merupakan gua tebing atau ceruk payung (rockshelter) berbentuk memanjang dan secara administratif termasuk wilayah Desa Tuanatuk, Kecamatan Lobalain. Gua Lua Manggetek terletak pada $10^{\circ} 45^{\prime} 19.9^{\prime \prime}$ Lintang Selatan dan $123^{\circ} 02^{\prime} 08,1^{\prime \prime}$ Bujur Timur dengan ketinggian 115 meter di atas permukaan air laut (dpl). Gua ini menghadap Timur laut $\left(\mathrm{N} 20^{\circ} \mathrm{E}\right)$, dengan kemiringan $30^{\circ}$. Gua payung berbentuk memanjang ini terletak 3 meter dari dataran, memiliki ornament gua berupa stalaktit, stalagmit, dan pilar. Sirkulasi udara baik dan intensitas sinar terang serta termasuk dalam kriteria gua layak huni, namun sayangnya kondisi gua sudah mengalami kerusakan karena banyak digali secara liar untuk mendapatkan kotoran burung walet. Berdasarkan hasil pengamatan permukaan di sekitar gua banyak didapatkan petunjuk temuan berupa serpih litik dan batu inti serta fragmen cangkang kerang secara melimpah.

\section{* Gua Landalilo}

Gua Landalilo merupakan gua kaki bukit yang termasuk wilayah Desa Lekik, Kecamatan Rote Barat Daya. Gua Landalilo terletak pada $10^{\circ}$ $51^{\prime} 06,0^{\prime \prime}$ Lintang Selatan dan $122^{\circ} 59^{\prime} 42,8^{\prime \prime}$ Bujur Timur dengan ketinggian 15 meter di atas permukaan air laut (dpl). Gua ini menghadap Barat (N250 ${ }^{\circ} \mathrm{E}$ ) dengan lebar mulut gua 16 meter, dari mulut gua ke dinding dalam 7,5 meter, serta tinggi mulut gua 10 meter. Sirkulasi udara maupun intensitas sinar cukup baik, serta terdapat ornamen berupa stalaktit dan stalagmit. Batuan penyusun gua ini adalah batu gamping yang mempunyai wama segar putih kekuningan dan lapuk berwama putih kecoklatan. Bentang alamnya termasuk pada morfologi karst, dan di depan gua ini mengalir Sungai Oe Ulu. Berdasarkan hasil pengamatan permukaan di sekitar gua tidak didapatkan petunjuk adanya temuan arkeologis.

\section{* Gua Safu}

Gua Safu merupakan gua kaki bukit yang termasuk wilayah Desa Lekik, Kecamatan Rote Barat Daya. Gua Safu terletak pada $10^{\circ} 51^{\prime} 17,7$ Lintang Selatan dan $122^{\circ} 59^{\prime} 38,8^{\prime \prime}$ Bujur Timur, dengan ketinggian 6 meter di atas permukaan air laut (dpl). Gua ini menghadap Barat (N290 $\left.{ }^{\circ} \mathrm{E}\right)$ dengan sirkulasi udara dan intensitas sinar yang baik, serta mempunyai ornamen berupa stalaktit dan stalagmit. Batuan penyusun situs ini adalah batugamping yang mempunyai wama segar putih kekuningan dan lapuk berwarna putih kecoklatan. Bentang alamnya termasuk pada morfologi karst. Berdasarkan hasil pengamatan permukaan di sekitar gua tidak didapatkan petunjuk adanya temuan arkeologis. 


\section{* Gua (Lua) Mesalolo}

Gua (Lua) Mesalolo merupakan gua tebing yang termasuk wilayah Desa Oenitas, Kecamatan Rote Barat. Gua Lua Mesalolo terletak pada $10^{\circ} 50^{\prime} 52,2^{\prime \prime}$ Lintang Selatan dan 122 59'38,8" Bujur Timur, dengan ketinggian 91 meter dari permukaan air laut $(\mathrm{dpl})$. Gua ini berarah hadap Barat $\left(\mathrm{N} 230^{\circ} \mathrm{E}\right)$ dengan kemiringan lereng $30^{\circ}$ dan terletak 30 meter dari dataran, dengan sirkulasi udara dan intensitas sinar yang baik. Ukuran lebar pintu gua 4 meter, tinggi pintu gua 2,5 meter, dan panjang ke dalam 4 meter. Gua tebing ini mempunyai ornamen berupa stalaktit dan stalagmit. Di dalam gua tidak ditemukan adanya lapisan sedimen atau tanah gua. Batuan penyusun situs ini adalah batugamping yang mempunyai warna segar putih kekuningan dan lapuk berwama putih kecoklatan. Bentang alamnya termasuk pada morfologi karst. Berdasarkan hasil pengamatan permukaan di sekitar gua tidak didapatkan petunjuk adanya temuan arkeologis.

\section{* Gua Tolobalu}

Gua Tolobalu merupakan gua tebing yang termasuk wilayah Desa Oenitas, Kecamatan Rote Barat. Gua Tolobalu terletak pada $10^{\circ} 50^{\prime} 54,9^{\prime \prime}$ Lintang Selatan dan $122^{\circ} 52^{\prime} 35,5^{\prime \prime}$ Bujur Timur, dengan ketinggian 74 meter di atas permukaan air laut $(\mathrm{dpl})$. Gua ini berarah hadap Tenggara $\left(\mathrm{N} 130^{\circ} \mathrm{E}\right)$ dengan kemiringan $15^{\circ}$, lebar pintu gua 15 meter dan panjang ke dalam 4 meter, tinggi pintu gua 3 meter. Sirkulasi udara dengan intensitas sinar yang baik, dan mempunyai omamen berupa stalaktit dan stalagmit. Di dalam gua tidak ditemukan adanya lapisan sedimen atau tanah gua. Batuan penyusun situs ini adalah batugamping yang mempunyai warna segar putih kekuningan dan lapuk berwama putih kecoklatan. Bentang alamnya termasuk pada morfologi karst. Berdasarkan hasil pengamatan permukaan di sekitar gua tidak didapatkan temuan arkeologis.

\section{* Gua Boa}

Gua Boa merupakan gua kaki bukit yang termasuk wilayah Desa Boa, Kecamatan Rote Barat. Gua Boa terletak pada $10^{\circ} 56^{\prime} 06,5^{\prime \prime}$ Lintang Selatan dan $122^{\circ} 50^{\prime} 34,4^{\prime \prime}$ Bujur Timur dengan ketinggian 3 meter di atas permukaan air laut (dpl). Gua ini berarah hadap Tenggara $\left(\mathrm{N} 130^{\circ} \mathrm{E}\right)$, lebar pintu gua 4 meter, tinggi pintu gua 1,7 meter, dan panjang ke dalam 2 meter, dengan sirkulasi udara dan intensitas sinar yang baik, serta mempunyai ornamen berupa stalaktit dan stalagmit. Batuan penyusun situs ini adalah batugamping yang mempunyai warna segar putih kekuningan dan lapuk berwarna putih kecoklatan. Bentang alamnya termasuk pada morfologi karst. Berdasarkan hasil pengamatan permukaan di sekitar gua tidak didapatkan temuan arkeologis.

\section{* Gua (Lua) Meo}

Gua (Lua) Meo merupakan gua tebing yang termasuk wilayah Desa Owe Milan, Kecamatan Rote Barat Laut. Gua Lua Meo terletak pada $10^{\circ} 46{ }^{\prime} 38,1^{\prime \prime}$ Lintang Selatan dan $122^{\circ} 01^{\prime} 00,8^{\prime \prime}$ Bujur Timur dengan 
ketinggian 134 meter di atas permuakaan air laut (dpl). Gua ini menghadap Timur $\left(\mathrm{N} 90^{\circ} \mathrm{E}\right)$ dengan kemiringan $40^{\circ}$. Gua ini merupakan lorong memanjang model kekar tiang (columnar joint). Sirkulasi udara dan intensitas sinar yang masuk cukup baik. Gua ini terletak lebih tinggi 15 meter dari dataran di sekitamya. Batuan penyusun situs ini adalah batugamping yang mempunyai wama segar putih kekuningan dan lapuk berwarna putih kecoklatan. Bentang alamnya termasuk pada morfologi karst. Berdasarkan hasil pengamatan permukaan di sekitar gua banyak didapatkan serpih litik dan batu inti serta fragmen cangkang kerang.

\section{* Gua (Lua) Oe}

Gua (Lua) Oe merupakan gua kaki bukit yang termasuk wilayah Kelurahan Mokdale, Kecamatan Lobalain. Gua Lua Oe terletak pada $10^{\circ} 44^{\prime} 55,0^{\prime \prime}$ Lintang Selatan dan $123^{\circ} 03^{\prime} 10,9^{\prime \prime}$ Bujur Timur dengan ketinggian 101 meter di atas permukaan air laut (dpl). Gua ini berarah hadap Barat laut ( $\mathrm{N} 330^{\circ} \mathrm{E}$ ), dengan lebar pintu gua 12 meter, tinggi pintu gua 2 meter, dan panjang ke dalam 15 meter. Sirkulasi udara dan intensitas sinar baik. Lantai gua miring kedalam, dan gua ini merupakan sungai bawah tanah. Batuan penyusun situs ini adalah batugamping yang mempunyai warna segar putih kekuningan dan lapuk berwarna putih kecoklatan. Bentang alamnya termasuk pada morfologi karst. Berdasarkan hasil pengamatan permukaan di sekitar gua tidak didapatkan temuan arkeologis.

\section{* Gua Harak Kecil}

Gua Harak kecil merupakan gua kaki bukit yang termasuk wilayah Desa Sotimori, Kecamatan Rote Timor. Gua Harak Kecil terletak pada $10^{\circ} 34^{\prime} 17,9^{\prime \prime}$ Lintang Selatan dan $123^{\circ} 19^{\prime} 46,1^{\prime \prime}$ Bujur Timur, dengan ketinggian 28 meter di atas permukaan air laut (dpl). Gua ini berarah hadap Utara $\left(\mathrm{N} 10^{\circ} \mathrm{E}\right)$, dengan lebar pintu gua 4 meter, tinggi pintu gua 3 meter, dan panjang ke dalam 3 meter. Di gua ini banyak ditemukan serpih litik dan kerang. Sirkulasi udara maupun intensitas sinar baik. Batuan penyusun situs ini adalah batugamping yang mempunyai warna segar putih kekuningan dan lapuk berwama putih kecoklatan. Bentang alamnya termasuk pada morfologi karst.

\section{* Gua Harak Utama}

Gua Harak Utama merupakan gua kaki bukit yang termasuk wilayah Desa Sotimori, Kecamatan Rote Timor. Gua Harak Utama terletak pada $10^{\circ} 34^{\prime} 20,2^{\prime \prime}$ Lintang Selatan dan $123^{\circ} 19^{\prime} 46,9^{\prime \prime}$ Bujur Timur, dengan ketinggian 23 meter di atas permukaan air laut (dpl). Gua ini menghadap Timur laut ( $\mathrm{N} 45^{\circ} \mathrm{E}$ ), dengan lebar pintu gua 5 meter yang di bagian tengahnya terdapat pilar batu, tinggi pintu gua 4 meter, dan panjang ke dalam 4 meter. Di gua ini banyak ditemukan serpih litik, kerang, dan sampah dapur (?). Sirkulasi udara maupun intensitas sinar yang masuk ke dalam cukup baik. 
Batuan penyusun situs ini adalah batugamping yang mempunyai warna segar putih kekuningan dan lapuk berwarna putih kecoklatan. Bentang alamnya termasuk pada morfologi karst.

\section{* Gua Aleksander}

Gua Aleksander merupakan gua kaki bukit dengan tipe gua 'Luweng' yang berada di wilayah Desa Dalehulu, Kecamatan Rote Selatan. Gua Aleksander terletak pada $10^{\circ} 46{ }^{\prime} 09,2^{\prime \prime}$ Lintang Selatan dan $123^{\circ} 09^{\prime} 09,7^{\prime \prime}$ Bujur Timur dengan ketinggian 306 meter di atas permukaan air laut (dpl). Gua ini menghadap Barat Laut (N345 ${ }^{\circ} \mathrm{E}$ ), dengan lebar pintu gua 5 meter, tinggi pintu gua 2 meter, dan panjang ke dalam \pm 100 meter. Sirkulasi udara sedang dan intensitas sinar buruk (kurang). Batuan penyusun situs ini adalah batugamping yang mempunyai warna segar putih kekuningan dan lapuk berwama putih kecoklatan. Bentang alamnya termasuk pada morfologi karst. Berdasarkan hasil pengamatan permukaan di sekitar gua tidak didapatkan indikator temuan arkeologis.

\section{* Gua Kaiseu-1}

Gua (Lua) Kaiseu-1 merupakan gua tebing yang termasuk wilayah Dusun Towiu, Desa Oetutulu, Kecamatan Rote Barat Laut,. Gua Kaiseu-1

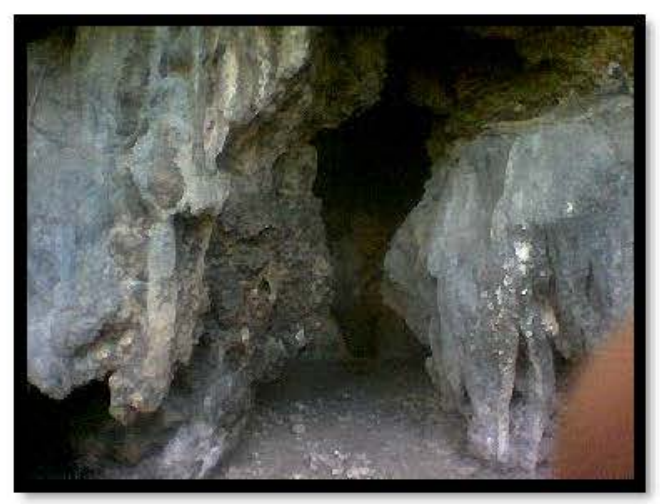

Foto 7. Gua Harak Utama

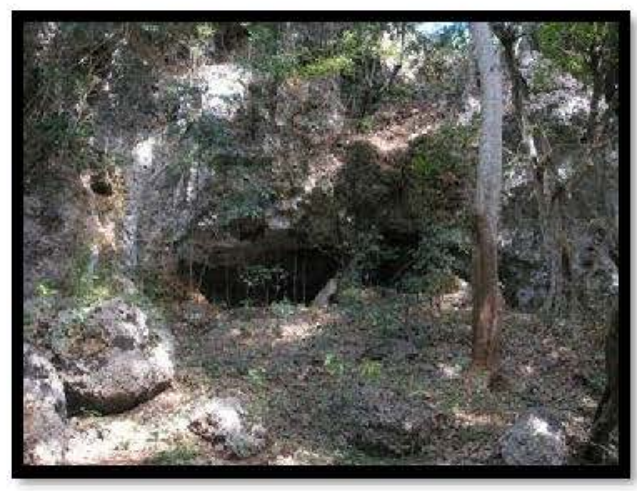

Foto 8. Gua Kaiseu-1

terletak pada $10^{\circ} 46^{\prime} 06,0^{\prime \prime}$ Lintang Selatan $123^{\circ} 00^{\prime} 36,7^{\prime \prime}$ Bujur Timur, dengan ketinggian 154 meter di atas permukaan air laut (dpl). Gua ini berarah hadap timur $\left(\mathrm{N}^{\circ} 0^{\circ} \mathrm{E}\right)$, dengan kemiringan $10^{\circ}$ dan ketinggian 2 meter dari dataran. Lebar pintu masuk 7,60 meter, tinggi pintu 2,45 meter. Ukuran ruang gua adalah panjang lorong 6,30 meter, tinggi ruang dari lantai ke atap 3,34 meter. Memiliki omamen stalagtit, stalakmit, pilar, batu alir (flowstone), dengan sirkulasi udara dan intensitas sinar yang baik. Di permukaan gua ini tidak ditemukan adanya indikasi bekas hunian. Jarak Gua Kaiseu-1 ke Gua Kaiseu-2 adalah 13 meter arah barat laut $\left(\mathrm{N} 333^{\circ} \mathrm{E}\right)$, ke Gua Kaiseu- 3 adalah 45 meter ke arah utara (N16 ${ }^{\circ}$ ), ke Gua Bai Henek Luan adalah 570 meter arah timur laut $\left(\mathrm{N} 38^{\circ} \mathrm{E}\right)$, ke mata air adalah 391 meter arah utara $\left(\mathrm{N} 9^{\circ} \mathrm{E}\right)$. Batuan penyusun situs ini adalah batugamping yang mempunyai warna segar putih kekuningan dan lapuk berwarna putih kecoklatan. Bentang 
alamnya termasuk pada morfologi karst. Berdasarkan hasil pengamatan permukaan di sekitar gua tidak didapatkan temuan arkeologis.

\section{* Gua Kaiseu-2}

Gua (Lua) Kaiseu-2 merupakan gua tebing yang termasuk wilayah Dusun Towiu, Desa Oetutulu, Kecamatan Rote Barat Laut. Gua Kaiseu-2 terletak pada $10^{\circ} 46{ }^{\prime} 05,6^{\prime \prime}$ Lintang Selatan $123^{\circ} 00^{\prime} 36,5^{\prime \prime}$ Bujur timur, dengan ketinggian 155 meter di atas permukaan air laut (dpl). Gua ini menghadap timur $\left(\mathrm{N} 75^{\circ} \mathrm{E}\right)$, dengan kemiringan $10^{\circ}$ dan ketinggian 2 meter dari dataran. Lebar mulut gua 3,3 meter, tinggi pintu gua 2,2 meter. Ukuran ruang gua adalah panjang lorong 10 meter, lebar ruang 3,3 meter, tinggi ruang dari lantai ke atap 3,2 meter. Gua ini memiliki omamen stalagtit, stalakmit, pilar, batu alir (flowstone), dengan sirkulasi udara dan intensitas sinar yang baik. Di permukaan gua ini ditemukan adanya tanda-tanda bekas hunian manusia berupa cangkang kerang.

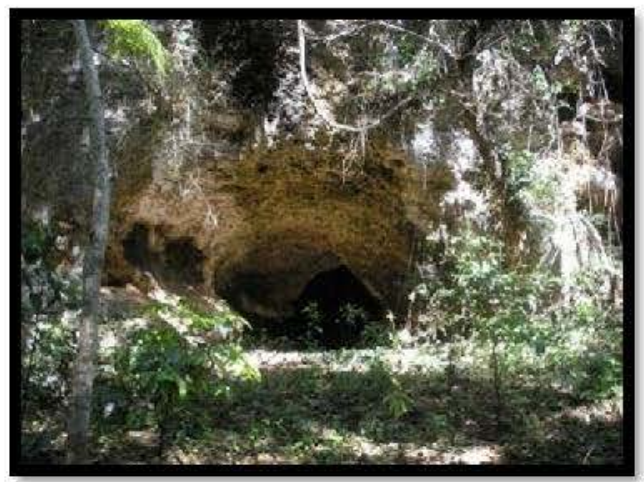

Foto 9. Pintu masuk Gua Kaiseu-2

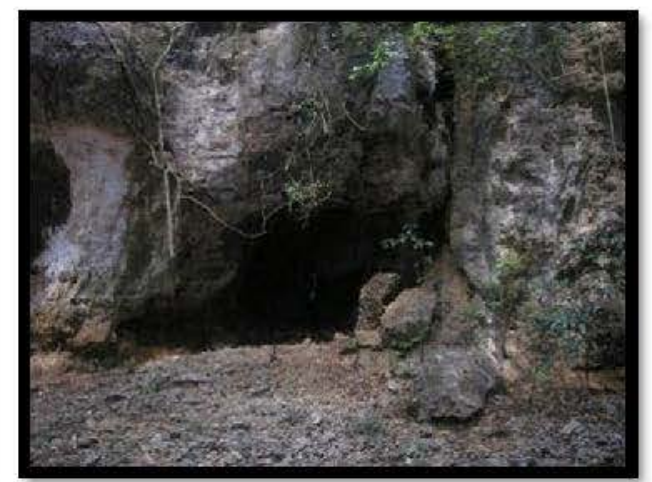

Foto 10. Gua Kaiseu-3

Jarak Gua Kaiseu-2 ke Gua Kaiseu-1 adalah 13 meter arah tenggara $\left(\mathrm{N} 153^{\circ} \mathrm{E}\right)$, ke Gua Kaiseu-3 adalah 36 meter arah timur laut $\left(\mathrm{N} 30^{\circ} \mathrm{E}\right)$, ke Gua Bai Henek Luan adalah 566 meter arah timur laut (N39 $\left.{ }^{\circ} \mathrm{E}\right)$, ke mata air adalah 381 meter arah utara $\left(\mathrm{N} 11^{\circ} \mathrm{E}\right)$. Batuan penyusun situs ini adalah batugamping yang mempunyai warna segar putih kekuningan dan lapuk berwarna putih kecoklatan. Bentang alamnya termasuk pada morfologi karst.

\section{* Gua Kaiseu-3}

Gua (Lua) Kaiseu-3 merupakan gua tebing yang termasuk wilayah Dusun Towiu, Desa Oetutulu, Kecamatan Rote Barat Laut. Gua Kaiseu-3 terletak pada $10^{\circ} 46^{\prime} 04,6^{\prime \prime}$ Lintang Selatan $123^{\circ} 00^{\prime} 36,7^{\prime \prime}$ Bujur Timur, dengan ketinggian 155 meter di atas permukaan air laut (dpl).

Gua ini menghadap timur laut $\left(\mathrm{N}^{\circ} \mathrm{O}^{\circ} \mathrm{E}\right)$, dengan kemiringan $10^{\circ}$ dan ketinggian 3 meter dari dataran. Lebar pintu masuk 5,4 meter, tinggi pintu 3,15 meter. Ukuran ruang gua berbentuk lorong ini adalah panjang 17,7 meter, lebar 4,5 meter, tinggi ruang dari lantai ke atap 4,4 meter. Di gua ini 
terdapat ornamen stalagtit, stalakmit, pilar, batu alir (flowstone), Sirkulasi udara maupun intensitas sinar-nya baik. Di permukaan gua ini tidak ditemukan adanya indikasi bekas hunian. Jarak Gua Kaiseu-3 ke Gua Kaiseu-1 adalah 45 meter ke arah selatan $\left(\mathrm{N} 197^{\circ} \mathrm{E}\right)$, ke Gua Kaiseu-2 adalah 36 meter ke arah barat daya $\left(\mathrm{N} 212^{\circ} \mathrm{E}\right)$, ke Gua Bai Henek Luan adalah 529 meter ke arah timur laut $\left(\mathrm{N} 40^{\circ} \mathrm{E}\right)$, ke mata air adalah 347 meter ke arah utara $\left(\mathrm{N}^{\circ} \mathrm{E}\right)$. Batuan penyusun situs ini adalah batugamping yang mempunyai warna segar putih kekuningan dan lapuk berwarna putih kecoklatan. Bentang alamnya termasuk pada morfologi karst.

\section{* Gua Bai Henek Luan}

Gua (Lua) Bai Henek Luan merupakan gua tebing yang termasuk wilayah Dusun Towiu, Desa Oetutulu, Kecamatan Rote Barat Laut. Gua Bai Henek Luan terletak pada $10^{\circ} 45^{\prime} 51,4^{\prime \prime}$ Lintang Selatan $123^{\circ} 00^{\prime} 48,2^{\prime \prime}$ Bujur Timur, dengan ketinggian 167 meter di atas permukaan air laut (dpl). Gua ini menghadap tenggara $\left(\mathrm{N} 120^{\circ} \mathrm{E}\right)$, dengan keminingan $30^{\circ}$ dan ketinggian 6 meter dari dataran. Lebar pintu masuk 4,9 meter, tinggi pintu 2,45 meter. Ukuran ruang gua adalah panjang lorong 11,6 meter, lebar ruang 10,5 meter, tinggi ruang dari lantai ke atap 4,7 meter. Gua ini tidak memiliki ornamen. Sirkulasi udara dan intensitas sinar baik. Di permukaan gua ini tidak ditemukan adanya indikasi bekas hunian.

Jarak Gua Bai Henek Luan ke Gua Kaiseu-1 adalah 570 meter arah barat daya $\left(\mathrm{N} 218^{\circ} \mathrm{E}\right)$ dan ke Gua Kaiseu-2 adalah 565 meter arah barat daya $\left(\mathrm{N} 219^{\circ} \mathrm{E}\right)$, ke Gua Kaiseu3 adalah 529 meter arah barat daya

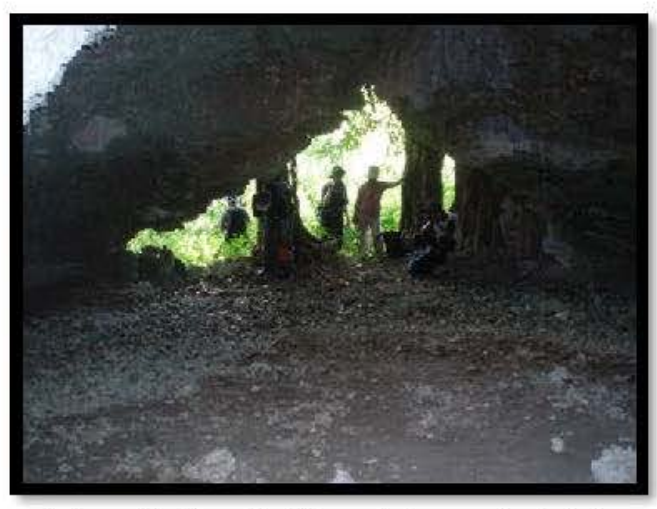

Foto 11. Gua Bai Henek Luan dari dalam $\left(\mathrm{N} 220^{\circ} \mathrm{E}\right)$, serta ke mata air adalah 294 meter arah barat $\left(\mathrm{N} 258^{\circ} \mathrm{E}\right)$. Batuan penyusun situs ini adalah batugamping yang mempunyai warna segar putih kekuningan dan lapuk berwama putih kecoklatan. Bentang alamnya termasuk pada morfologi karst.

\section{* Situs Paleolitik Sungai Kola}

Sungai Kola adalah situs terbuka yang termasuk dalam kategori situs paleolitik dan merupakan wilayah Desa Nggodimeda, Kecamatan Rote Tengah. Situs ini terletak pada koordinat $10^{\circ} 39^{\prime} 34,7^{\prime \prime}$ Lintang Selatan dan $123^{\circ} 09^{\prime} 17,7^{\prime \prime}$ Bujur Timur dengan ketinggian 13 meter di atas permukaan air laut (dpl). Bentang alam situs merupakan aliran sungai atau situs terbuka. Sungai Kola termasuk dalam satuan morfologi dataran yang tersusun oleh batugamping berupa singkapan (outcrop), berwarna segar putih kekuningan dan lapuk berwarna kuning kecoklatan. Sungai yang 
terdapat di situs ini adalah Sungai Kola (stadia tua) yang berarah aliran selatan ke utara.

Artefak-artefak yang ditemukan berasal dari batuan chert (rijang) dan jasper. Dalam pengamatan, tidak ditemukan singkapan batuan yang dapat diduga sebagai sumber bahan artefak. Namun, batuan sejenis hanya ditemukan dalam bentuk bungkahan (boulder).

Di sepanjang dasar dan bantaran sungai terdapat sebaran kerakal dari berbagai jenis batuan. Artefak Paleolitik terdapat di antara sebaran batu tersebut, berupa alat-alat serpih berukuran besar dan alat batu inti. Penemuan situs ini sangat penting karena sejauh ini baru pertama kali ditemukan di Pulau Rote. Untuk mengetahui lebih jauh tentang keberadaan budaya Paleolitik di pulau ini perlu dilakukan penelusuran daerah aliran sungai ke hulu. Sangat disayangkan, saat ini penduduk melakukan pengambilan kerakal sungai untuk dipecah-pecah dan dijual sebagai bahan bangunan. Kegiatan ini telah menghilangkan sebagian data penting tentang hunian tertua prasejarah daerah ini.

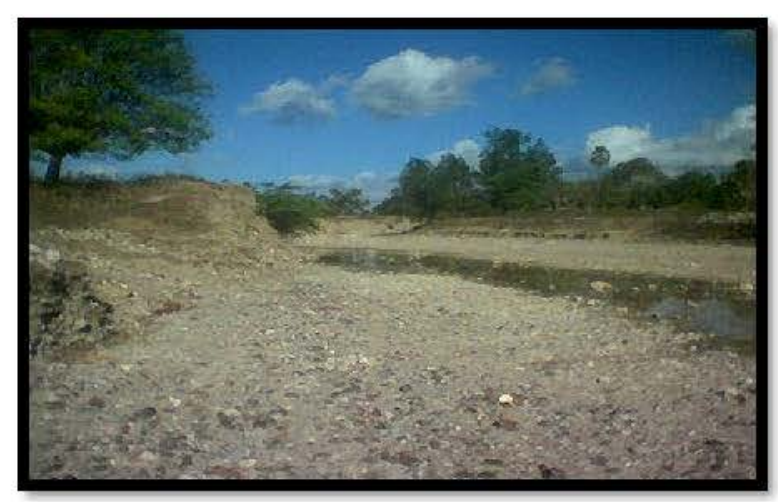

Foto 12. Situs Paleolitik Sungai Kola 
TABEL SEBARAN GUA-GUA DAN CERUK DI PULAU ROTE

\begin{tabular}{|c|c|c|c|c|c|c|}
\hline $\mathrm{NO}$ & NAMA SITUS & $\begin{array}{c}\text { DESA } \\
\text { KELURAHAN }\end{array}$ & KECAMATAN & KOORDINAT & ARAH HADAP & $\begin{array}{l}\text { INDIKATOR } \\
\text { TEMUAN }\end{array}$ \\
\hline 1 & $\begin{array}{l}\text { Gua Lua } \\
\text { Manggetek }\end{array}$ & Tuanatuk & Lobalain & $\begin{array}{l}10^{\circ} 45^{\prime} 19.9^{\prime \prime} \mathrm{LS} \\
123^{\circ} 02^{\prime} 08,1^{\prime \prime B T}\end{array}$ & Timur laut $\left(\mathrm{N} 20^{\circ} \mathrm{E}\right)$ & Serpih litik, kerang \\
\hline 2 & Gus Mbia Hudale & Mokdale & Mokdale & $\begin{array}{l}10^{\circ} 44^{\prime} 51,0^{\prime \prime} \text { LS } 123^{\circ} \\
03^{\prime} 15.0^{\prime \prime} \text { BT }\end{array}$ & Barat $\left(\mathrm{N} 270^{\circ} \mathrm{E}\right)$ & $\begin{array}{l}\text { Serpih litik, } \\
\text { cangkang kerang }\end{array}$ \\
\hline 3 & Gua Londalilo & Lekik & Rote Barat Daya & $\begin{array}{l}10^{\circ} 51^{\prime} 06,0^{\prime \prime} \text { LS } 122^{\circ} \\
59^{\prime} 42,8^{\prime \prime} . \mathrm{BT}\end{array}$ & Barat $\left(\mathrm{N} 250^{\circ} \mathrm{E}\right)$ & - \\
\hline 4 & Gua Safu & Lekik & Rote Barat Daya & $\begin{array}{l}10^{\circ} 51^{\prime} 17,7^{\prime \prime} \text { LS } \\
122^{\circ} 59^{\prime} 38,8^{\prime \prime} \text { BT }\end{array}$ & Barat $\left(\mathrm{N} 290^{\circ} \mathrm{E}\right)$ & - \\
\hline 5 & $\begin{array}{l}\text { Gua Lua } \\
\text { Mesalolo }\end{array}$ & Oenitas & Rote Barat & $\begin{array}{l}10^{\circ} 50 \text { '52,2" LS } \\
122^{\circ} 59 ' 38,8 \text { " BT }\end{array}$ & Barat $\left(\mathrm{N} 230^{\circ} \mathrm{E}\right)$ & - \\
\hline 6 & Gua Tolobalu & Oenitas & Rote Barat & $\begin{array}{l}10^{\circ} 50^{\prime} 54,9^{\prime \prime} \text { LS } \\
122^{\circ} 52 \text { '35,5" BT }\end{array}$ & Tenggara $\left(\mathrm{N} 130^{\circ} \mathrm{E}\right)$ & - \\
\hline 7 & Gua Boa & Boa & Rote Barat & $\begin{array}{l}10^{\circ} 56^{\prime} 06,5^{\prime \prime} \text { LS } \\
122^{\circ} 50 \text { '34,4" BT }\end{array}$ & Tenggara $\left(\mathrm{N} 130^{\circ} \mathrm{E}\right)$ & - \\
\hline 8 & Gua Lua Meo & Owe Milan & Rote Barat Laut & $\begin{array}{l}10^{\circ} 46^{\prime} 38,1^{\prime \prime} \text { LS } \\
122^{\circ} 01^{\prime} 00,8 \text { " BT }\end{array}$ & Timur $\left(\mathrm{N} 90^{\circ} \mathrm{E}\right)$ & $\begin{array}{l}\text { Serpih litik, } \\
\text { cangkang kerang }\end{array}$ \\
\hline 9 & Gua Lua Oe & Mokdale & Lobalain & $\begin{array}{l}10^{\circ} 44^{\prime} 55,0^{\prime \prime} \text { LS } \\
123^{\circ} 03^{\prime} 10,9^{\prime \prime} \text { BT }\end{array}$ & Barat laut $\left(\mathrm{N} 330^{\circ} \mathrm{E}\right)$ & - \\
\hline 10 & Gua Harak Kecil & Sotim ori & Rote Timur & $\begin{array}{l}10^{\circ} 34^{\prime} 17,9^{\prime \prime} \text { LS } \\
123^{\circ} 19^{\prime} 46,1^{\prime \prime} \text { BT }\end{array}$ & Utara $\left(\mathrm{N} 10^{\circ} \mathrm{E}\right)$ & $\begin{array}{l}\text { Serpih litik, } \\
\text { cangkang kerang }\end{array}$ \\
\hline 11 & $\begin{array}{l}\text { Gua Harak } \\
\text { Utama }\end{array}$ & Sotimori & Rote Timur & $\begin{array}{l}10^{\circ} 34^{\prime} 20,2^{\prime \prime} \text { LS } \\
123^{\circ} 19^{\prime} 46,9^{\prime \prime} \text { BT }\end{array}$ & Timur laut $\left(\mathrm{N} 45^{\circ} \mathrm{E}\right)$ & $\begin{array}{l}\text { Serpih, cangkang } \\
\text { kerang, tulang }\end{array}$ \\
\hline 12 & Gua Aleksander & Delehulu & Rote Selatan & $\begin{array}{l}10^{\circ} 46^{\prime} 09,2^{\prime \prime} \text { LS } \\
123^{\circ} 09^{\prime} 09,7^{\prime \prime} \text { BT }\end{array}$ & Barat laut $\left(\mathrm{N} 345^{\circ} \mathrm{E}\right)$ & - \\
\hline 13 & Gua Bafak & Oe Matamboli & Lobalain & $\begin{array}{l}10^{\circ} 45^{\prime} 37,3^{\prime \prime ~ L S ~} \\
123^{\circ} 07^{\prime} 24,5^{\prime \prime} \text { BT }\end{array}$ & Selatan $\left(\mathrm{N} 170^{\circ} \mathrm{E}\right)$ & $\begin{array}{l}\text { Serpih, cangkang } \\
\text { kerang, tembikar, } \\
\text { tulang }\end{array}$ \\
\hline
\end{tabular}

Berkala Arkeologi Tahun XXXX Edisi No. 1 / Mei zoro 


\begin{tabular}{|c|c|c|c|c|c|c|}
\hline $\mathrm{NO}$ & NAMA SITUS & $\begin{array}{c}\text { DESA } \\
\text { KELURAHAN }\end{array}$ & KECAMATAN & KOORDINAT & ARAH HADAP & $\begin{array}{l}\text { INDIKATOR } \\
\text { TEMUAN }\end{array}$ \\
\hline 14 & Gua Bote & Oe Matamboli & Lobalain & $\begin{array}{l}10^{\circ} 45^{\prime} 58,6^{\prime \prime} \text { LS } \\
123^{\circ} 07^{\prime} 48,6^{\prime \prime} \text { BT }\end{array}$ & Barat laut $\left(\mathrm{N} 300^{\circ} \mathrm{E}\right)$ & $\begin{array}{l}\text { Serpih, cangkang } \\
\text { kerang, tembikar, } \\
\text { manik-manik } \\
\text { kerang }\end{array}$ \\
\hline 15 & Gua Kaiseu-1 & Oetutulu & Rote Barat Laut & $\begin{array}{l}10^{\circ} 46^{\prime} 06,0^{\prime \prime} \text { LS } \\
123^{\circ} 00^{\prime} 36,7^{\prime \prime} \text { BT }\end{array}$ & Timur (N90 & - \\
\hline 16 & Gua Kaiseu-2 & Oetutulu & Rote Barat Laut & $\begin{array}{l}10^{\circ} 46^{\prime} 05,6^{\prime \prime} \text { LS } \\
123^{\circ} 00 \text { ' } 36,5^{\prime \prime} \text { BT }\end{array}$ & Timur $\left(\mathrm{N} 75^{\circ} \mathrm{E}\right)$ & Cangkang kerang \\
\hline 17 & Gua Kaiseu-3 & Oetutulu & Rote Barat Laut & $\begin{array}{l}10^{\circ} 46^{\prime} 04,6 \text { " LS } \\
123^{\circ} 00 \text { '36,7" BT }\end{array}$ & Timur Laut $\left(\mathrm{N} 60^{\circ} \mathrm{E}\right)$ & - \\
\hline 18 & $\begin{array}{l}\text { Gua Bai Henek } \\
\text { Luan }\end{array}$ & Oetutulu & Rote Barat Laut & $\begin{array}{l}10^{\circ} 45^{\prime} 51,4^{\prime \prime} \mathrm{LS} \\
123^{\circ} 00^{\prime} 48,2^{\prime \prime} \mathrm{BT}\end{array}$ & Tenggara $\left(\mathrm{N} 120^{\circ} \mathrm{E}\right)$ & Cangkang kerang \\
\hline 19 & Sungai Kola & Nggodi Meda & Rote Tengah & $\begin{array}{l}10^{\circ} 39^{\prime} 34,7^{\prime \prime} \text { LS } \\
123^{\circ} 09^{\prime} 17,7^{\prime \prime} \text { BT }\end{array}$ & - & $\begin{array}{l}\text { Artefak batu } \\
\text { (paleolitik) }\end{array}$ \\
\hline
\end{tabular}




\section{PENUTUP}

Hasil penelitian yang telah diuraikan dalam tulisan ini memang masih belum mencapai target dan sasaran secara keseluruhan. Hal tersebut disebabkan oleh berbagai kendala, di antaranya faktor pendanaan dan waktu yang relatif singkat dalam pelaksanaan di lapangan. Namun setidaknya penelitian ini telah memberikan masukan dan tambahan data tentang berbagai temuan (dari hasil ekskavasi) dan gambaran sebaran guagua maupun ceruk serta berbagai potensi sumberdaya lingkungan di wilayah ini.

Survei dan pengamatan yang dilakukan di lokasi penelitian berhasil menemukan setidaknya 18 gua dan ceruk serta situs paleolitik di sepanjang Sungai Kola yang menunjukkan adanya temuan alat serpih batu dan batu inti. Namun, harus diakui, tidak semua gua dan ceruk yang ditemukan pernah dimanfaatkan sebagai tempat hunian atau tempat tinggal manusia pada masa lalu. Sebagian hanya merupakan gua-gua alam atau bekas lorong-lorong sungai bawah tanah yang tidak menunjukkan adanya tinggalan arkeologis. Selain itu, penelitian ini juga berhasil mendata sejumlah lokasi sumber bahan baku (batuan) yang dipakai alat-alat litik dan memberikan gambaran keadaan geologi di sekitar daerah penelitian.

Sementara itu, melalui penggalian kotak-kotak uji di Gua Mbia Hudale, Gua (Lua) Bafak, dan Gua Bote berhasil ditemukan sejumlah tinggalan arkeologis, baik berupa artefak maupun ekofak, yang merupakan bukti dari aktivitas hunian manusia pada masa lalu yang berlangsung sejak Akhir Plestosen hingga Kala Holosen. Tinggalan tersebut antara lain berupa: artefak batu, fragmen tembikar, manik-manik kerang, sisa-sisa tulang dan gigi fauna serta cangkang kerang (moluska) yang ditemukan sangat melimpah. Situs Gua Bafak dan Gua Bote kemungkinan merupakan gua-gua yang dipakai sebagai tempat hunian manusia pada Kala Holosen; sedangkan Situs Gua Mbia Hudale dihuni sejak akhir Kala Plestosen (Mahirta, 2006). Berdasarkan jenis-jenis tinggalan budaya dan karakteristik gua, kemungkinan situs-situs tersebut dipakai sebagai ajang aktivitas pembuatan artefak litik dan tempat tinggal sementara manusia masa lalu.

Apabila penelitian terdahulu telah mengungkapkan kekayaan gua dan ceruk di Pulau Rote, melalui penelitian yang relatif singkat ini semakin terbukti bahwa Pulau Rote temyata mempunyai potensi gua dan ceruk yang sangat melimpah dengan kandungan data arkeologi yang diharapkan mampu menguak lebih luas sejarah masa lalu daerah ini. Wilayah Pulau Rote mempunyai tinggalan budaya maupun gua-gua hunian manusia pada masa lalu yang belum terungkapkan. Gua dan ceruk ini masih perlu diteliti secara lebih intensif dan berkelanjutan. Meskipun penelitian ini belum dapat menjawab semua pertanyaan yang dikemukakan di atas, namun setidaknya kandungan dan potensi tinggalan arkeologis yang terdapat di dalam guagua dan ceruk di Pulau Rote merupakan data yang penting bagi pengembangan penelitian di wilayah ini. Penelitian arkeologi yang dilakukan 
di Pulau Rote ini merupakan langkah awal dalam tindak lanjut penelitian mendatang di wilayah ini.

\section{KEPUSTAKAAN}

Anderson, Douglas. 1990. Lang Rongrien Rockshelter: a Pleistocene-Early Holocene Archaeological site from Krabi, Southwestern Thailand, University Museum Monography 71, Philadelpia: The University Museum.

Barker, Graeme, H.W. Barton, Paul Beavitt, Patrick Daly, Chris Doherty, David Gilbertson, Chris Hunt, John Krigbaum, Helen Lewis, Jessica Manser, Sue McClaren, Victor Paz, Phil Piper, Brian Pyatt, Ryan Rabett, Tim Reynolds, Jim Rose, Garry Rushworth and Mark Stephens. 2002. "Prehistoric foragers and farmers in South-east Asia: Renewed investigations at Niah Cave, Sarawak". Proceedings of the Prehistoric Society, 68.147-164.

Bellwood, Peter, Goenadi Nitihaminoto, Geoffrey Irwin, Gunadi, Agus Waluyo \& Daud Tanudirjo. 1998. "35,000 Years of prehistory in the northern Moluccas". Dalam Gert-Jan Bartstra (ed), Bird's Head approaches. Inan Jaya studies - a programme for interdisiplinary research. Rotterdam: A.A.Balkema. 233- 275.

Birdsell, J.B. 1977. "The Recalibration of a Paradigm for the First Peopling of Greater Australia". Dalam Allen, J., J. Golson, \& R. Jones (eds.). Sunda and Sahul: Studies in Southeast Asia, Melanesia and Australia: 113-167. London Academic Press.

Bulbeck, David, Iwan Sumantri, dan Peter Hiscock. 2004. Modern Quaternary Research in Southeast Asia. 18:111-128

Butzer, Karl W, 1964 Environment and Archaelogy. Methuen. London.

Eriawati, Y.J. dan Intan S. Fadhlan M., 1995 'Gua-Gua Di Maros Dan Pangkep, Sulawesi Selatan'. Laporan Penelitian Bidang Arkeometri, Puslit Arkenas. Jakarta (tidak terbit)

Glover, I.C. 1981. "Leang Burung 2: An Upper Palaeolithic Rock Shelter in South Sulawesi". Modern Quaternary Research in Southeast Asia, 6. $1-38$.

Jatmiko, 2008. 'Penelitian Gua-Gua Hunian Pada Kala Holosen di Pulau Rote, Kabupaten Rotendao, Provinsi Nusa Tenggara Timur (TahapI). LPA Puslitbang Arkenas. Jakarta (tidak terbit) 
Jatmiko, 2009. 'Penelitian Gua-Gua Hunian Pada Kala Holosen di Pulau Rote, Kabupaten Rotendao, Provinsi Nusa Tenggara Timur (TahapII)'. LPA Puslitbang Arkenas. Jakarta (tidak terbit)

Mahirta. 2004. "Human Occupation on Roti and Sawu Islands, Nusa Tenggara Timur". Disertasi. Australian National University.

O'Connor, Susan, Matthew Spriggs \& Peter Veth, 2000 "Excavation at Lene Hara Cave Establishes Occupation in East Timor at least 30.00035.000 Years Ago". Antiquity 76: 45-50

Pasveer, Juliette. 2003. "The Djief Hunters. 26,000 years of Lowland Rainforest Exploitation on the Bird's Head of Papua, Indonesia". Rijksuniversiteit Groningen (diss).

Simanjuntak, Truman. 2001. "New light on the prehistory of the Southem Mountains of Java", Indo-Pacific Prehistoric Association Bulletin, (Melaka paper), no.21, vol.5. 152-156.

Spriggs, Matthew. 1998. "The archaeology of the Bird's Head in its Pacific and Southeast Asian context", dalam Miedema, Cecilia Odé, Rien A.C. Dam (eds), Perspectives on the Bird's Head of Irian Jaya, Indonesia, Amsterdam: Rodop: 931-940. 